\title{
Laryngeal Cancer cN2b TNM Finding v8
}

National Cancer Institute

\section{Source}

National Cancer Institute. Laryngeal Cancer cN2b TNM Finding v8. NCI Thesaurus. Code C133134.

Laryngeal cancer with metastases in multiple ipsilateral lymph nodes, none more than 6 $\mathrm{cm}$ in greatest dimension and ENE(-). (from AJCC 8th Ed.) 